\title{
HUBUNGAN ANTARA SIKAP, KEPERCAYAAN DAN TRADISI, SERTA PERAN \\ PETUGAS KESEHATAN DENGAN PERILAKU PEMBERIAN ASI EKSKLUSIF PADA IBU YANG MEMILIKI BAYI USIA 7-12 BULAN DI WILAYAH KERJA UPT PUSKESMAS MANGUNREJA KABUPATEN TASIKMALAYA TAHUN 2019
}

\author{
OLEH : \\ Novi Siti Patimah, S. K. M, Sinta Fitriani, S.KM,M.KM, \\ Hariyani Sulistiyoningsih, S.KM,M.KM
}

(novisitipatimah95@gmail.com)

\section{A. ABSTRAK}

Latar Belakang : ASI Eksklusif adalah sumber nutrisi yang banyak manfaatnya bagi bayi. Cakupan ASI Eksklusif di Wilayah UPT Puskesmas Mangunreja pada tahun 2018 sebesar 39,0\%. Penelitian ini bertujuan untuk mengetahui hubungan antara sikap, kepercayaan dan tradisi serta peran petugas kesehatan dengan perilaku pemberian ASI Eksklusif pada ibu yang memiliki bayi usia 7-12 bulan di Wilayah UPT Puskesmas Mangunreja Kabupaten Tasikmalaya tahun 2019.

Metode Penelitian : Penelitian ini menggunakan jenis penelitian kuantitatif, metode analitik, desain cross sectional. Populasi penelitian ini adalah ibu yang memiliki bayi usia 7-12 bulan, dengan sampel penelitian 296 orang. Dengan Teknik proportional random sampling. Instrumen penelitian lembar kuesioner, Analisis data menggunakan uji Chi-Square.

Hasil Penelitian : Hasil penelitian menyatakan bahwa variabel yang berhubungan signifikan dengan perilaku ASI Eksklusif adalah sikap dengan value 0,001 dan kepercayaan tradisi $p$ value 0,001, sedangkan variabel dukungan peran petugas kesehatan tidak berhubungan dengan p value 0,164> 0,05.

Saran : Meningkatkan cakupan ASI Eksklusif dengan memberikan informasi, edukasi tentang ASI Eksklusif dan fakta, mitos ibu menyusui dengan penyuluhan atau media promosi kesehatan lainnya.

Kata Kunci : ASI Eksklusif, Sikap, Kepercayaan, Tradisi, Peran Petugas Kesehatan.

\section{B. PENDAHULUAN}

Anak sebagai generasi bangsa penerus bangsa yang merupakan aset yang sangat berharga berhak mendapatkan perlindungan dengan diberikan nutrisi terbaik yang mengandung zat gizi untuk pertumbuhan dan perkembangannya hal ini ditegaskan dalam PERMENKES Nomor 450/2004 (Sri Astuti, et all ; 2015 : 114). Pemerintah mengeluarkan peraturan percepatan perbaikan gizi yang diatur dalam Peraturan Presiden No 42 Tahun 2013 tentang Gerakan Nasional Percepatan Perbaikan Gizi yang fokus pada 1000 hari pertama kehidupan (HPK), yang termasuk dalam Hari Pertama Kehidupan (HPK) salah satunya adalah pemberian ASI Eksklusif selama 6 Bulan (Depkes, 2016).

Sesuai dengan Peraturan Pemerintah Nomor 33 Tahun 2012 tentang pemberian Air Susu Ibu Eksklusif, air susu ibu atau disingkat ASI adalah cairan hasil sekresi kelenjar payudara ibu. ASI Eksklusif adalah ASI yang diberikan pada bayi sejak dilahirkan selama enam bulan tanpa menambah dan/atau mengganti dengan makanan atau minuman lain. (INFODATIN, 2018).

Berdasarkan hasil Riskesdas tahun 2018 yaitu proporsi ASI Eksklusif pada bayi usia 0-5 bulan di Indonesia sebesar (37,5\%), proporsi tertinggi pemberian ASI pada bayi usia 0-5 bulan tahun 2018 
adalah provinsi Kepulauan Bangka Belitung (56,7\%), Sedangkan provinsi dengan proporsi terendah adalah provinsi Nusa Tenggara Barat (20,3\%), Adapun proporsi pemberian ASI pada bayi usia $0-5$ bulan provinsi Jawa Barat (JABAR) sebesar (35,0\%). (Profil Riskesdas, 2018). Berdasarkan data Dinas Kesehatan Kabupaten Tasikmalaya tahun 2017 di Kecamatan Mangunreja Cakupan bayi yang mendapatkan ASI eksklusif yaitu sebesar (10,34\%) dengan jumlah bayi sebanyak 677 usia 7-59 bulan, dari data tersebut Kecamatan Mangunreja menjadi urutan pertama cakupan ASI Eksklusif yang paling rendah sekabupaten Tasikmalaya. (Profil DINKES Kabupaten Tasikmalaya, 2017)

Berdasarkan data profil UPT Puskesmas Mangunreja pada tahun 2016 cakupan ASI Eksklusif yaitu sebesar (43,3\%), sedangkan pada tahun 2017 cakupan ASI Eksklusif sebesar (50,9\%), serta pada tahun 2018 cakupan ASI Eksklusif yaitu sebesar (39,0\%). (Profil Puskesmas Mangunreja, 2016-2018).

Berdasarkan latar belakang diatas peneliti ingin melakukan penelitian dengan topik hubungan antara sikap, kepercayaan dan tradisi serta peran petugas kesehatan dengan perilaku pemberian ASI Eksklusif pada ibu yang memiliki bayi usia 7-12 bulan di Wilayah UPT Puskesmas Mangunreja Kabupaten Tasikmalaya tahun 2019.

\section{METODOLOGI PENELITIAN}

1. Populasi

Populasi dalam penelitian ini adalah seluruh ibu yang memiliki bayi usia 7-12 bulan di Wilayah Kerja UPT Puskesmas Mangunreja Periode Maret 2019 yaitu sebanyak 296 orang.

2. Sampel

Teknik pengambilan sampel dalam penelitian ini adalah dengan menggunakan " Proportional Random Sampling “
Tabel 1.1 Proporsi Sampel

\begin{tabular}{llll}
\hline No & Dusun & Populasi & $\begin{array}{l}\text { Sampel } \\
\text { yang } \\
\text { diambil }\end{array}$ \\
\hline 1 & Mangunreja & 66 & 37 \\
2 & Margajaya & 49 & 27 \\
3 & Sukasukur & 51 & 28 \\
4 & Salebu & 55 & 30 \\
5 & Sukaluyu & 32 & 18 \\
6 & pasirsalam & 43 & 24 \\
\hline & Jumlah & 296 & 164 \\
\hline
\end{tabular}

(Sumber : Data Profil UPT Puskesmas Mangunreja tahun 2018)

3. Instrumen Penelitian

Instrumen dalam penelitian yang digunakan adalah kuesioner yang terdiri dari:

a) Variabel Sikap

Jumlah kuesioner sikap adalah 8 pernyataan terdiri dari 4 pernyataan positif dan 4 pernyataan negatif. Penilain sikap untuk penyataan positif yang menjawab setuju diberi nilai 1 , jika pernyataan positif yang menjawab tidak setuju diberi nila 0 . Sedangkan pernyataan negatif yang menjawab setuju diberi nilai 0 , dan jika pernyataan negatif yang menjawab tidak setuju diberi nilai 1 .

b) Variabel Kepercayaan Jumlah kuesionernya adalah 3 pertanyaan dengan penilaian jika ibu menjawab pernyataan negatif iya maka diberi nilai 0 , dan jika penyataan negatif ibu menjawab tidak maka diberi nilai 1. Sedangkan jika ibu menjawab pernyataan positif iya maka diberi nilai 1, dan jika ibu menjawab pernyataan positif tidak maka diberi nilai 0 .

c) Variabel Peran Petugas Kesehatan

Variabel peran petugas terdiri dari 9 pernyataan dengan penilaian sebagai berikut : Untuk pernyataan negatif apabila dijawab ya maka diberikan nilai 0 dan apabila dijawab tidak maka nilai 1 .

d) Perilaku pemberian ASI

Penilaian perilaku pemberian ASI disimpulkan ASI Eksklusif apabila hanya diberikan ASI saja pada usia 0-6 bulan. 
e) Uji Validitas

Instrumen yang digunakan telah dilakukan uji validitas dan reliabilitas di Dusun Pameungpeuk Desa Cikunir di Wilayah Kerja UPT Puskesmas Singaparna terhadap ibu yang memiliki bayi usia 7-12 bulan periode maret 2019.

4. Analisis Data

a. Analisis Univariat

Analisis univariat dalam penelitian ini dilakukan untuk memperoleh distribusi frekuensi dan presentase dari setiap variabel baik mendeskripsikan ataupun menjelaskan variabel bebas dan variabel terikat. Analisis ini bertujuan untuk memberoleh gambaran distribusi frekuensi dari variabel bebas yaitu sikap, keperayaan, peran petugas kesehatan. Dan variabel terikat yaitu perilaku ibu dalam pemberian ASI Eksklusif pada bayi.

b. Analisis Bivariat

Analisis bivariat dalam penelitian ini dilakukan untuk mengetahui hubungan antara variabel bebas sikap, kepercayaan, peran tenaga kesehatan, dan variabel terikat yaitu perilaku dengan menggunakan Uji Chi-Square dengan menggunakan program SPSS. Kriteria pengjian dengan menggunakan distribusi p-value dibandingkan dengan (0.05). apabila hasil uji statistik $\mathrm{p}<0,05$ artinya ada hubungan yang bermakna (Ho diterima dan $\mathrm{H}_{\mathrm{I}}$ ditolak).

\section{Hasil Penelitian}

\section{Analisis Univariat}

a. Gambaran Perilaku Ibu Dalam Pemberian ASI Eksklusif Pada Ibu Yang Memiliki Bayi Usia 7-12 Bulan Di Desa Mangunreja Di Wilayah Kerja UPT Puskesmas Mangunreja Tahun 2019.

Berdasarkan hasil penelitian yang telah dilakukan dapat diketahui bahwa distribusi perilaku ibu dalam pemberian ASI Eksklusif pada bayi di Desa Mangunreja tahun 2019.

Gambaran Perilaku Ibu Dalam Pemberian ASI Eksklusif Pada Ibu Yang Memiliki Bayi Usia 7-12 Bulan Di Desa Mngunreja Di Wilayah Kerja UPT Puskesmas Mangunreja Tahun 2019

\begin{tabular}{llll}
\hline $\begin{array}{c}\text { Perilaku Pemberian } \\
\text { Eksklusif }\end{array}$ & ASI & Total & $\begin{array}{c}\text { Persentase } \\
\mathbf{( \% )}\end{array}$ \\
\hline ASI Eksklusif & & 78 & 47,6 \\
Tidak ASI Eksklusif & 86 & 52,4 \\
\hline Jumlah & 164 & 100 \\
\hline
\end{tabular}

Berdasarkan tabel 5.5 didapatkan bahwa ibu yang memiliki bayi usia 7-12 bulan di Desa Mangunreja di Wilayah Kerja UPT Puskesmas Mangunreja terdapat 86 orang $(52,4 \%)$ yang tidak memberikan ASI secara Eksklusif.

Berdasarkan hasil responden tidak memberikan ASI Eksklusif menyatakan bayi diberi MP ASI sejak lahir. Alasan tidak diberikan ASI secara eksklusif responden menyatakan disebabkan karena pada awal kelahiran ASInya sedikit. 


\section{b. Gambaran Sikap Ibu Dalam Pemberian ASI Eksklusif Pada Ibu Yang Memiliki Bayi Usia 7-12 Bulan Di Desa Mangunreja Di Wilayah Kerja UPT Puskesmas Mangunreja Tahun 2019.}

Berdasarkan hasil penelitian yang telah dilakukan dapat diketahui bahwa distribusi sikap ibu dalam pemberian ASI Eksklusif pada bayi di Desa Mangunreja tahun 2019.

Gambaran Sikap Ibu Dalam Pemberian ASI Eksklusif

Pada Ibu Yang Memiliki Bayi Usia 7-12 Bulan Di Desa Mangunreja Di Wilayah Kerja UPT Puskesmas Mangunreja Tahun 2019

\begin{tabular}{lll}
\hline $\begin{array}{l}\text { Sikap Ibu Dalam Pemberian ASI } \\
\text { Eksklusif }\end{array}$ & Total & Persentase (\%) \\
& & \\
\hline Mendukung & 136 & 82,9 \\
Tidak Mendukung & 28 & 17,1 \\
\hline Jumlah & 164 & 100 \\
\hline
\end{tabular}

Berdasarkan tabel 5.6 didapatkan bahwa ibu yang memiliki bayi usia 7-12 bulan yang mempunyai sikap tidak mendukung ASI Eksklusif adalah 28 orang $(17,1 \%)$.

Terdapat 163 responden $(99,4 \%)$ mayoritas setuju ASI Eksklusif bisa meningkatkan kasih sayang ibu dan anak. Sedangkan masih terdapat responden yang menyatakan tidak setuju terhadap pernyataan ASI pertama (kolostrum) dapat mencegah penyakit seperti risiko diare sebanyak 142 orang $(86,6 \%)$ serta Bayi yang diberikan ASI saja dapat memenuhi kebutuhan bayi sehingga dapat terhindar dari penyakit Hiperbilirubin (Kuning) yaitu 137 orang $(83,5 \%)$

c. Gambaran Kepercayaan Dan Tradisi Ibu Dalam Pemberian ASI Eksklusif Pada Ibu Yang Memiliki Bayi Usia 7-12 Bulan Di Desa Mangunreja Di Wilayah Kerja UPT Puskesmas Mangunreja Tahun 2019.

Berdasarkan hasil penelitian yang telah dilakukan dapat diketahui bahwa distribusi kepercayaan dan tradisi ibu dalam pemberian ASI Eksklusif pada bayi di Desa Mangunreja tahun 2019.

Gambaran Kepercayaan Dan Tradisi Ibu Dalam Pemberian ASI Eksklusif Pada Ibu Yang Memiliki Bayi Usia 7-12 Bulan Di Desa Mangunreja Di Wilayah Kerja UPT Puskesmas Mangunreja Tahun 2019

Kepercayaan dan Tradisi Ibu Total
Dalam Pemberian ASI Eksklusif

\begin{tabular}{lll}
\hline Tidak Percaya & 9 & 5,5 \\
Percaya & 155 & 94,5 \\
\hline Jumlah & 164 & 100 \\
\hline
\end{tabular}

Berdasarkan tabel 5.8 didapatkan bahwa mayoritas ibu yang memiliki bayi usia 7-12 bulan memiliki kepercayaan terhadap mitos tentang ASI dan menyusui yaitu 155 orang $(94,5 \%)$.

Mayoritas kepercayaan yang dimiliki oleh ibu adalah menyusui dapat menyebabkan payudara kendur dan Bayi sering menangis merupakan tanda tidak tercukupinya kebutuhan bayi sehingga perlu diberikan susu formula. 


\section{d. Gambaran Peran Petugas Kesehatan Dalam Pemberian ASI Eksklusif Pada Ibu Yang Memiliki Bayi Usia 7-12 Bulan Di Desa Mngunreja Di Wilayah Kerja UPT Puskesmas Mangunreja Tahun 2019.}

Berdasarkan hasil penelitian yang telah dilakukan dapat diketahui bahwa distribusi kepercayaan dan tradisi ibu dalam pemberian ASI Eksklusif pada bayi di Desa Mangunreja tahun 2019.

Gambaran Peran Petugas Kesehatan Dalam Pemberian ASI Eksklusif Pada Ibu yang Memiliki Bayi Usia 7-12 bulan Di Desa Mngunreja Di Wilayah Kerja UPT Puskesmas Mangunreja Tahun 2019

\begin{tabular}{lll}
\hline $\begin{array}{l}\text { Peran Petugas Kesehatan Dalam } \\
\text { Pemberian ASI Eksklusif }\end{array}$ & Total & Persentase (\%) \\
& & \\
\hline Mendukung & 133 & 81,1 \\
Tidak Mendukung & 31 & 18,9 \\
\hline Jumlah & 164 & 100 \\
\hline
\end{tabular}

Berdasarkan tabel 5.9.1 didapatkan bahwa ibu yang memiliki bayi usia 7-12 bulan di Desa Mangunreja di Wilayah Kerja UPT Puskesmas Mangunreja yang tidak mendapatkan dukungan dari tenaga kesehatan yaitu 31 orang $(18,9 \%)$.

Berdasarkan tabel 5.9.2 distribusi peran petugas didapatkan bahwa mayoritas responden menyatakan bahwa petugas kesehatan memberikan informasi tentang pentingnya ASI eksklusif sebanyak 162 orang (98,8\%). Sedangkan terdapat 16 respoden $(9,8 \%)$ yang menyatakan bahwa petugas kesehatan menawarkan susu formula pada bayi usia $0-6$ bulan serta 13 responden (7,9\%) Petugas kesehatan tidak menyarankan pemberian susu formula sebagai upaya mencegah penyakit kuning atau hiperbilirubin

\section{Analisis Bivariat}

Analisis bivariat digunakan untuk melihat hubungan antara variabel dependen dan variabel independen yaitu perilaku pemberian ASI Eksklusif dengan variabel independent yaitu Sikap, kepercayaan dan tradisi serta peran petugas kesehatan dengan menggunakan uji Chi-Square.

Hasil analisis bivariat antara sikap dengan perilaku ibu dalam pemberian ASI Eksklusif disajikan dalam tabel 5.9.2 di bawah ini:

Hubungan antara sikap dengan perilaku ibu yang memiliki usia 7-12 bulan dalam pemberian ASI Eksklusif di Desa Mangunreja di Wilayah Kerja UPT Puskesmas Mangunreja Tahun 2019.

\begin{tabular}{|c|c|c|c|c|c|c|c|}
\hline \multirow[t]{3}{*}{ Sikap } & \multicolumn{7}{|c|}{ Perilaku Pemberian ASI Eksklusif } \\
\hline & \multirow{2}{*}{\multicolumn{2}{|c|}{ ASI Eksklusif }} & Tic & & \multirow{2}{*}{\multicolumn{2}{|c|}{ Total }} & $\mathrm{P}$ \\
\hline & & & & & & & Value \\
\hline & $\mathrm{F}$ & $\%$ & $\mathrm{~F}$ & $\%$ & $\mathrm{~F}$ & $\%$ & \\
\hline Mendukung & 73 & 53,7 & 63 & 46,3 & 136 & 100 & \\
\hline Tidak Mendukung & 5 & 17,9 & 23 & 82,1 & 28 & 100 & 0,001 \\
\hline Jumlah & 78 & 47,6 & 86 & 52,4 & 164 & 100 & \\
\hline
\end{tabular}


Berdasakan tabel 5.9.3 didapatkan bahwa 73 orang $(53,7 \%)$ yang memiliki sikap mendukung dapat memberikan ASI secara eksklusif, sedangkan terdapat 5 orang $(17,9 \%)$ responden yang memiliki sikap kurang mendukung dapat memberikan ASI secara eksklusif.

Berdasarkan hasil uji chi-square didapatkan $\mathrm{p}$ value $0,001<0,05$ adalah Ho ditolak artinya terdapat hubungan antara sikap dengan pemberian ASI eksklusif pada ibu yang memiliki bayi usia $7-12$ bulan di Desa Mangunreja di Wilayah Kerja UPT Puskesmas Mangunreja tahun 2019.

Hasil analisis bivariat antara kepercayaan dan tradisi dengan perilaku ibu dalam pemberian ASI Eksklusif disajikan dalam tabel 5.9.2 di bawah ini:

Hubungan antara kepercayaan dan tradisi dengan perilaku ibu yang memiliki bayi usia 7-12 bulan dalam pemberian ASI Eksklusif di Desa Mangunreja di Wilayah Kerja UPT Puskesmas Mangunreja Tahun 2019.

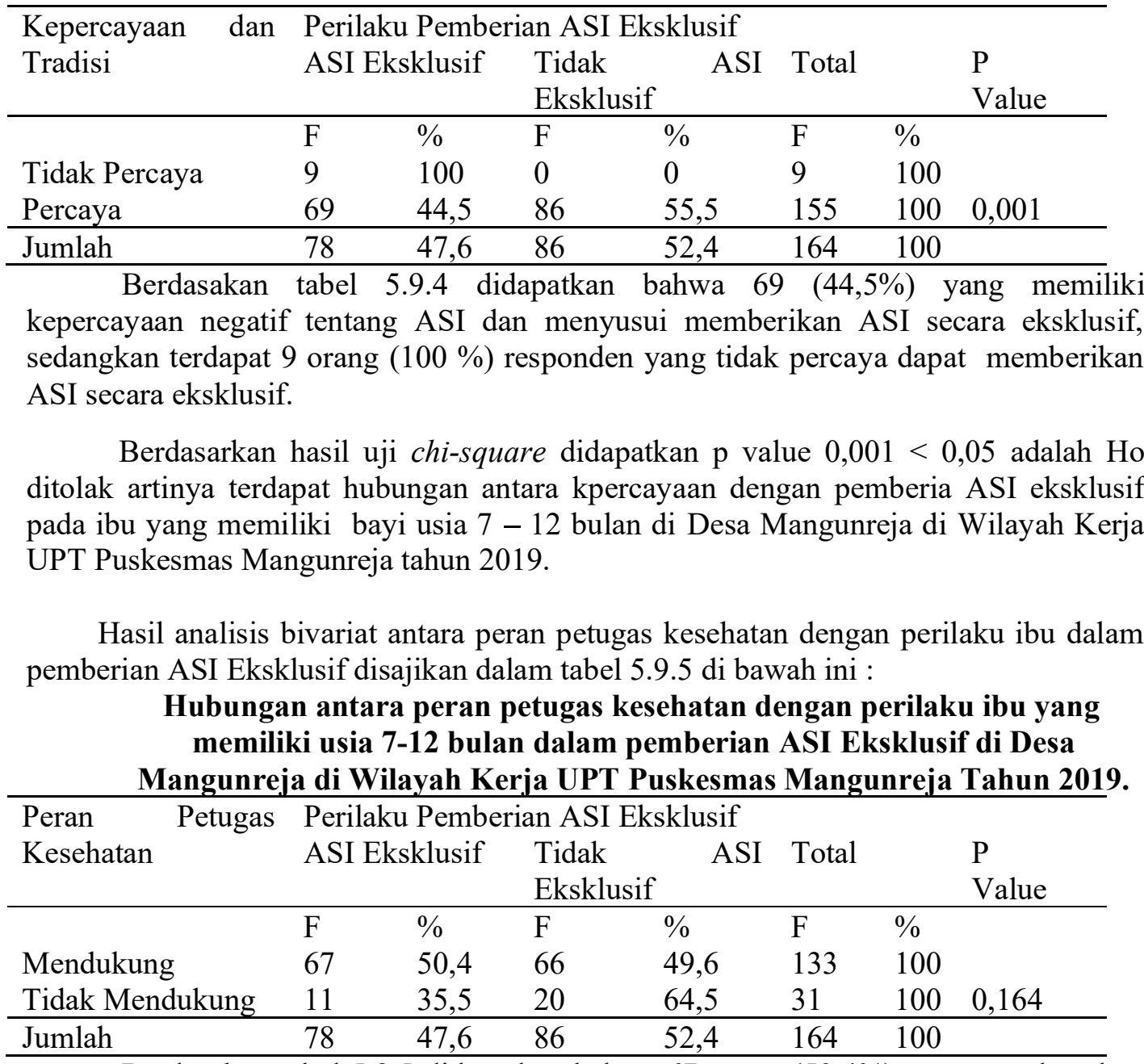

Berdasakan tabel 5.9 .5 didapatkan bahwa 67 orang $(50,4 \%)$ yang mendapatkan dukungan dari tenaga kesehatan dapat memberikan ASI secara eksklusif, sedangkan terdapat $11(35,5 \%)$ responden yang tidak mendapat dukungan dari tenaga kesehatan dapat memberikan ASI secara eksklusif.

Berdasarkan hasil uji chi-square didapatkan $\mathrm{p}$ value $0,164>0,05$ adalah Ho gagal ditolak artinya tidak terdapat hubungan antara dukungan petugas kesehhatan 
dengan pemberian ASI eksklusif pada ibu yang memiliki bayi usia $7-12$ bulan di Desa Mangunreja di Wilayah Kerja UPT Puskesmas Mangunreja tahun 2019.

\section{E. PEMBAHASAN}

1. Hubungan Antara Sikap dengan Perilaku Ibu Yang Memiliki Bayi Usia 7-12 Bulan dalam pemberian ASI Eksklusif.

Berdasarkan tabel 5.6 didapatkan bahwa ibu yang memiliki bayi usia 7-12 bulan yang mempunyai sikap tidak mendukung ASI Eksklusif adalah 28 orang $(17,1 \%)$.

Sikap merupakan suatu bentuk evaluasi atau reaksi perasaan, sikap dipandang sebagai perasaan baik memihak ataupun melawan suatu objek psikologis. Sikap seseorang adalah perasaan mendukung atau memihak maupun perasaan tidak mendukung atau memihak objek tertentu, sikap mempunyai peran penting dalam menjelaskan perilaku seseorang dalam lingkungannya walaupun masih banyak faktor lain yang mempengaruhi perilaku seperti stimulus, latar belakang, individu, motivasi dan status kepribadian. Secara timbal balik faktor lingkungan juga mempengaruhi sikap dan perilaku (Sri dan Nuriah, 2017).

Menurut Azwar (2016) yang dikutip dari Asri (2017) bahwa sikap tentang pemberian ASI Eksklusif merupakan faktor yang menentukan seseorang untuk bersedia atau kesiapan untuk memberikan ASI secara eksklusif. Jika ibu sudah memiliki sikap yang kuat dalam memberikan ASI Eksklusif, maka perilakunya menjadi lebih konsisten.

Hasil penelitian yang dilakukan di Desa Mangunreja di Wilayah Kerja UPT Puskesmas Mangunreja dapat diketahui bahwa responden yang sikapnya mendukung serta memberikan ASI Eksklusif sebanyak 73 orang $(53,7 \%)$, dan responden yang sikapnya mendukung tetapi tidak memberikan ASI Eksklusif sebanyak 63 orang
(46,3\%). Sedangkan responden yang sikapnya tidak mendukung yang memberikan ASI Eksklusif sebanyak 5 orang $(17,9 \%)$, dan responden yang tidak mendukung serta tidak memberikan ASI Eksklusif sebanyak 23 orang $(82,1 \%)$. Hasil analisis menggunakan Uji Chi-Square diperoleh dari hasil bahwa $p$ value $0,001<\alpha 0,05$ sehingga $\mathrm{H}_{\mathrm{o}}$ di tolak. Artinya terdapat hubungan antara sikap dengan perilaku pemberian ASI Eksklusif.

Berdasarkan Distribusi jawaban responden yang menjawab sikap pernyataan mayoritas setuju ASI Eksklusif bisa meningkatkan kasih sayang ibu dan anak. Sedangkan akan tetapi masih terdapat responden yang menyatakan tidak setuju untuk pernyataan ASI pertama tidak harus dibuang karena tidak dapat menimbulkan risiko diare.

Hasil Penelitian ini sejalan dengan Risa Fadillah Daulay pada tahun 2018 " Hubungan Karakteristik, Pengetahuan Dan Sikap Ibu Dengan Pemberian ASI Eksklusif Di Wilayah Kerja Puskesmas Pekan Labuhan Kecamatan Medan Labuhan Kota Medan" menyatakan bahwa terdapat hubungan yang signifikan antara sikap ibu dengan pemberian ASI Eksklusif. Hal ini ditunjukan dengan menggunakan uji chi-square tidak dapat dilakukan karena terdapat dua sel yang nilai expected count kurang dari 5, sehingga menggunakan uji exact Fisher diperoleh $\mathrm{p}$ value $0,001<0,05$. Dari penelitian ini diartikan bahwa terdapat pengaruh antara sikap dengan perilaku pemberian ASI Eksklusif.

Rekomendasi peneliti untuk meningkatkan sikap positif perilaku dalam pemberian ASI Eksklusif dengan cara meningkatkan pengetahuan ibu, memperbanyak informasi tentang 
pentingnya ASI Eksklusif serta memberikan dukungan motivasi pada ibu menyusui untuk memberikan ASI secara eksklusif oleh petugas kesehatan dengan melalui kegiatan penyuluhan konseling atau media promosi kesehatan lainnya.

\section{Hubungan Antara Kepercayaan dan Tradisi dengan Perilaku Ibu Yang Memiliki Bayi Usia 7-12 Bulan dalam pemberian ASI Eksklusif}

Berdasarkan penelitian yang dilakukan di Desa Mangunreja di Wilayah Kerja UPT Puskesmas Mangunreja diketahui bahwa mayoritas ibu yang memiliki bayi usia 7-12 bulan memiliki kepercayaan terhadap mitos tentang ASI dan menyusui yaitu 155 orang $(94,5 \%)$

Menurut hatta (2010) yang dikutip melalui Farapti dan Setyaningsih (2017) bahwa tradisi dan kepercayaan berkembang sebagai sesuatu yang akan menggiring perilaku masyarakat untuk melakukan hal sesuai dengan tradisi dan kepercayaan yang ada dilingkungan mereka. Mitos ataupun kepercayaan adalah hal yang menghambat tindakan menyusui yang normal, beberapa mitos yang sering ada yaitu kolostrum yang terdapat dalam ASI tidak bagus bagi bayi, bayi akan mengalami kekurangan nutrisi jika diberi ASI saja, dari kepercayaan tersebut ibu akan memberikan makanan tambahan lain selain ASI untuk memenuhi kebutuhan nutrisi bagi bayi. Selain itu menurut Widodo (2006) diketahui bahwa adanya kepercayaan yang berkembang didalam masyarakat tentang menyusui bayi dapat membuat bentuk payudara berubah, yang menjadi salah satu penyebab paling signifikan tidak berhasilnya pemberian ASI secara eksklusif.

Hasil penelitian yang dilakukan di Desa Mangunreja di Wilayah Kerja
UPT Puskesmas Mangunreja dapat diketahui bahwa responden yang meyakini kepercayaan dan tradisi tetapi memberikan ASI Eksklusif sebanyak 69 orang $(44,5 \%)$, dan responden yang meyakini kepercayaan dan tradisi serta tidak memberikan ASI Eksklusif sebanyak 86 orang $(55,5 \%)$. Sedangkan responden yang tidak percaya dengan kepercayaan dan tradisi tetapi meberikan ASI Eksklusif sebanyak 9 orang $(100 \%)$, dan responden yang tidak percaya akan kepercayaan dan tradisi serta tidak memberikan ASI Eksklusif sebanyak 0 orang (0\%). Hasil analisis menggunakan Uji Chi-Square diperoleh dari hasil bahwa $\mathrm{p}$ value $0,001<\alpha 0,05$ sehingga $\mathrm{H}_{\mathrm{o}}$ di tolak. Artinya terdapat hubungan antara kepercayaan dan tradisi dengan perilaku pemberian ASI Eksklusif.

Berdasarkan distribusi jawaban responden diketahui mayoritas kepercayaan yang dimiliki oleh ibu adalah menyusui dapat menyebabkan payudara kendur dan susu formula dapat memenuhi kebutuhan bayi (menyebabkan bayi kenyang). Dan terdapat responden yang masih mempercayai ASI yang pertama keluar adalah ASI yang sudah basi.

Berdasarkan hasil penelitian Sinta dan Anisa tahun 2018 "Presepsi Dan Kebiasaan Masyarakat Dalam Pemenuhan Kebutuhan Gizi Ibu Dan Bayi Di Desa Cikunir Kecamatan Singaparna Kabupaten Tasikmalaya" didapatkan bahwa ibu yang memiliki kebiasaan membuang ASI pertama karena dianggap basi yaitu 72 orang $(43,9 \%)$.

Banyak ibu yang kurang atau kesalahan informasi sehingga terdapat mitos-mitos yang masih tersebar dikalangan ibu menyusui seperti payudara yang berukuran kecil dianggap kurang menghasilkan ASI, menyusui akan merubah payudara menjadi kendur, serta ASI tidak cukup pada hari-hari pertama sehingga bayi 
perlu makanan tambahan. Berdasarkan penelitian WHO pernah menyampaikan bahwa alasan terbanyak ibu menghentikan pemberian ASI Eksklusif karena ASI-nya tidak mencukupi kebutuhan bayi. Sekitar 35\% ibu menghentikan pemberian ASI secara Eksklusif pada beberapa minggu postpartum karena merasa ASI kurang dan bayi merasa tidak puas (Andina, $2018: 93$ )

Hasil penelitian ini sejalan dengan Setyaningsih dan Farapti pada tahun 2017 " Hubungan Kepercayaan Dan Tradisi Keluarga Pada Ibu Menyusui Dengan Pemberian ASI Eksklusif Di Kelurahan Sidotopo,Semampit, Jawa Timur Tahun 2017" menyatakan bahwa terdapat hubungan yang signifikan antara kepercayaan dan tradisi ibu dengan pemberian ASI Eksklusif. Hal ini ditunjukan dengan menggunakan uji chi-square diperoleh nilai kepercayaan $\mathrm{p}$ value 0,045 dan nilai tradisi $\mathrm{p}$ value 0,019 , hal tersebut menunjukan bahwa kedua nilai $\mathrm{p}$ value $<\alpha 0,05$. Dari penelitian ini diartikan bahwa terdapat pengaruh antara kepercayaan dan tradisi dengan perilaku pemberian ASI Eksklusif.

Rekomendasi peneliti untuk masyarakat tentang kepercayaan atau mitos yang berkembang perlu dilakukannya pendekatan antara lintas sektor,petugas kesehatan dalam merubah presepsi masyarakat tentang kepercayaan atau mitos dan tradisi yang ada dengan cara memberikan informasi dengan menggunakan media promosi kesehatan penyuluhan atau memutar film pendek untuk membandingkan antara fakta dan mitos tentang pemberian ASI Eksklusif.

\section{Hubungan Antara Peran Petugas Kesehatan Dengan Perilaku Ibu Yang Memiliki Bayi Usia 7-12 Bulan dalam pemberian ASI Eksklusif.}

Berdasarkan penelitian yang dilakukan di Desa Mangunreja di Wilayah Kerja UPT Puskesmas Mangunreja dapat diketahui bahwa mayoritas responden yang mendapatkan dukungan dari tenaga kesehatan yaitu sebanyak 133 orang $(81,1 \%)$.

Peran petugas kesehatan adalah promosi melalui Pendidikan kesehatan yang berperan penting dalam masyarakat. Petugas kesehatan harus dapat memberi informasi kepada ibu agar memberikan ASI Eksklusif pada bayinya dengan cara menjelaskan manfaat serta komposisi ASI dibandingkan dengan susu formula dan tidak memfasilitasi bayi baru lahir dengan susu formula (selferida, et all., 2017 : 88-95).

Hasil penelitian yang dilakukan di Desa Mangunreja di Wilayah Kerja UPT Puskesmas Mangunreja dapat diketahui bahwa responden yang mendapatkan dukungan dari petugas kesehatan kepada ibu yang memberikan ASI Eksklusif sebanyak 67 orang $(50,4 \%)$, dan petugas kesehatan yang mendukung tetapi ibu tidak memberikan ASI Eksklusif sebanyak 66 orang (49,6\%). Sedangkan petugas kesehatan yang tidak mendukung tetapi ibu memberikan ASI Eksklusif sebanyak 11 orang $(35,5 \%)$, dan petugas kesehatan yang tidak mendukung serta ibu yang tidak memberikan ASI Eksklusif sebanyak 20 orang (64,5\%). Hasil analisis menggunakan Uji Chi-Square diperoleh dari hasil bahwa $\mathrm{p}$ value $0,164 \geq \alpha 0,05$ sehingga $\mathrm{H}_{\mathrm{o}}$ di terima. Artinya tidak terdapat hubungan antara peran petugas kesehatan dengan perilaku pemberian ASI Eksklusif. 
Berdasarkan distribusi jawaban responden terhadap dukungan peran petugas kesehatan diketahui bahwa dukungan yang paling banyak dijawab responden petugas kesehatan memberikan informasi tentang pentingnya ASI eksklusif sebanyak 162 orang $(98,8 \%)$. Sedangkan responden menyatakan bahwa masih ada petugas kesehatan yang menawarkan susu formula pada bayi usia 0-6 bulan yaitu sebanyak 16 orang $(9,8 \%)$.

Hasil penelitian ini sejalan dengan Anung,. ett all pada tahun 2018 “ Beberapa Faktor Yang Mempengaruhi Praktik Ibu Dalam Pemberian ASI Eksklusif Di Wilayah Kerja Puskesmas Pegandan Kota Semarang " menyatakan bahwa tidak terdapat hubungan yang signifikan antara peran petugas kesehatan dengan pemberian ASI Eksklusif. Hal ini ditunjukan dengan menggunakan uji chi-square dengan nilai $\mathrm{p}$ value $0,192>$ a 0,05 maka Ho diterima dapat diartikan bahwa tidak terdapat hubungan antara peran petugas kesehatan dengan pemberian ASI Eksklusif.

Rekomendasi peneliti untuk petugas kesehatan yang masih ada menawarkan susu formula untuk tidak menawarkan serta memfasilitasi bayi baru lahir dengan susu formula, diharapkan petugas kesehatan menjalankan peran petugas kesehatan dengan berpedoman terhadap pasal 29 PP No 33 Tahun 2012 dan lebih meningkatkan upaya promotif seperti pemberian konseling dan penyuluhan tentang pentingnya ASI.

\section{F. Simpulan dan Saran \\ 1. Kesimpulan}

Berdasarkan hasil penelitian dan pembahasan mengenai hubungan antara sikap, kepercayaan dan tradisi serta peran petugas kesehatan dengan perilaku pemberian ASI Eksklusif pada ibu yang memiliki bayi usia 7-12 bulan di Wilayah UPT Puskesmas Mangunreja Kabupaten Tasikmalaya tahun 2019. Maka penulis menyimpulkan sebagai berikut :

a. Mayoritas ibu yang memiliki bayi usia 7-12 bulan di Desa Mangunreja di Wilayah Kerja UPT Puskesmas Mangunreja yang tidak memberikan ASI secara Eksklusif sebanyak 86 orang $(52,4 \%)$.

b. Terdapat sikap ibu yang tidak mendukung dalam pemberian ASI Eksklusif yaitu sebanyak 28 orang $(17,1 \%)$.

c. Mayoritas ibu yang meyakini kepercayaan dan tradisi negatif dalam pemberian ASI Eksklusif sebanyak 155 orang $(94,5 \%)$.

d. Terdapat peran petugas kesehatan yang tidak mendukung dalam pemberian ASI Eksklusif sebanyak $31(18,9 \%)$.

e. Terdapat hubungan yang signifikan antara sikap dengan perilaku ibu yang memiliki bayi usia 7-12 bulan dalam pemberian ASI Eksklusif di Desa Mangunreja di Wilayah Kerja UPT Puskesmas Mangunreja Tahun 2019 ( $p$ value : 0,001).

f. Terdapat hubungan yang signifikan antara kepercayaan dan tradisi dengan perilaku ibu yang memiliki bayi usia 7-12 bulan dalam pemberian ASI Eksklusif di Desa Mangunreja di Wilayah Kerja UPT Puskesmas Mangunreja Tahun 2019 ( $p$ value : 0,001 ).

g. Tidak terdapat hubungan yang signifikan antara peran petugas kesehatan dengan perilaku ibu yang memiliki bayi usia 7-12 bulan dalam pemberian ASI Eksklusif di Desa Mangunreja di Wilayah Kerja UPT Puskesmas Mangunreja Tahun 2019 ( $p$ value : 0,164).

\section{Saran}

a. Bagi Institusi Pendidikan

Institusi Pendidikan dapat berpartisipasi untuk meningkatkan cakupan ASI Eksklusif di masyarakat pada kegiatan 
pengabdian kepada masyarakat melalui kegiatan penyuluhan, konseling, dan sebagainya.

b. Bagi Masyarakat

Masyarakat dapat meningkatkan upaya pencarian informasi kesehatan khusunya ASI Eksklusif untuk mengubah kepercayaan yang diyakini melalui kegiatan menghadiri penyuluhan dipelayanan kesehatan atau di balai desa.

c. Bagi Pelayanan Kesehatan Puskesmas

Pelayanan kesehatan dapat meningkatkan pelayanan promotif melalui kegiatan penyediaan kesehatan dengan metode media promosi kesehatan secara berkesinambungan.

d. Bagi Tenaga Kesehatan

Petugas kesehatan dapat meningkatkan memberi dukungan terhadap ibu yang memberikan ASI melalui kegiatan motivasi dan menambahkan keyakinan untuk bisa memberi ASI Eksklusif melalui kegiatan konseling pada saat melaksanakan ANC (Antenatal Care). Petugas harus menerapkan dan mengingat pasal 29 PP No 33 Tahun 2012 tentang pemberian Air Susu Ibu Eksklusif bahwa menetapkan sanksi administrasi bagi tenaga kesehatan atau profesi di bidang kesehatan yang menjadi distributor susu formula atau produk bayi lainnya yang menghambat keberhasilan program pemberian Air Susu Ibu secara eksklusif.

\section{G. DAFTAR PUSTAKA}

Andina Vita Susanto. Asuhan

Kebidanan Nifas \& Menyusui. Pustaka Baru Press 2018

Dewi dan Nunung. Antropologi

Kesehatan. Pustaka Baru Press 2018 DINKES

Kabupaten

Tasikmalaya. (2017). Profil Dinas

Kesehatan Kabupaten Tasikmalaya dr. drh. Mangku Sitepoe, at all,.

ASI EKSKLUSIF Arti Penting Bagi

Kehidupan. Cetakan ke-1 2013

Eka Satriani Sakti, at all,. (2018). Menyusui sebagai Dasar
Kehidupan Tema Pekan ASI Sedunia, 17 Agustus 2018

Hesti Widuri. Cara Mengelola ASI Eksklusif Bagi Ibu Bekerja. Cetakan ke-1 2013

INFODATIN (Pusat Data Informasi Kementrian Kesehatan RI) 2018

Indra Iswari. (2018). Gambaran Pengetahuan Suami dari Ibu Menyusui (0-6 Bulan) Tentang ASI Eksklusif di Wilayah Kreja Puskesmas Dermayu Kabupaten Seluma Tahun 2017. Jurnal Of Midwifery. Volume 6 No. 1 (April 2018)

Jurnal Biometrika dan Kependudukan. Hubungan Kepercayaan dan Tradisi Keluarga Pada Ibu Menyusui dengan Pemberian ASI Eksklusif di Kelurahan Sidotopo, Semampir, Jawa Timur. Vol. 7, No. 2 Desember 2018 : 160-167

Notoatmodjo. Promosi Kesehatan dan Perilaku Kesehatan. Rineka Cipta. Cetkan ke-1 Maret 2012

Notoatmodjo. Metodologi Penelitian Kesehatan. Rineka Cipta 2014

Nurul Laily Hidayati. 1000 Hari Emas Pertama dari Persiapan Kehamilan Sampai Batita. Rapha Publishing 2014

Risa Fadillah Daulay (2018). Hubungan Karakteristik, Pengetahuan, dan Sikap Ibu dengan Pemberian ASI Eksklusif di Wilayah Kerja Puskesmas Pekan Labuhan Kecamatan Medan Labuhan Kota Medan Tahun 2018

RISKESDAS. (2018). Hasil Utama RISKESDAS 2018. Kementrian Kesehatan Badan Penelitian dan Pengembangan Kesehatan

Selferida, ett all,. (2017). Hubungan Pengetahuan Ibu, Paritas dan Peran Petugas Kesehatan dengan Pemberian ASI Eksklusif di Wilayah Kerja Puskesmas Siborongborong Tapanuli Utara Tahun 2017

Sinta Akmalia (2018). Faktorfaktor yang berhubungan dengan 
Pemberian ASI Eksklusif pada

Puskesmas Tinewati Kabupaten Tasikmalaya Tahun 2018

Sinta dan Annisa (2018). Persepsi dan Kebiasaan Masyarakat Dalam Pemenuhan Kebutuhan Gizi Ibu dan Bayi di Desa Cikunir Kecamatan Singaparna Kabupaten Tasikmalaya Tahun 2018

Tesy Mamonto. (2015). FaktorFaktor yang Berhubungan dengan
Bayi di Desa Cipakat Wilayah Kerja Pemberian ASI Eksklusif pada bayi di Wilayah Kerja Puskesmas Kotobangun Kecamatan KotaMobagu Timur Kota Kotamobagu

UPT Puskesmas Mangunreja. (2016). Profil Puskesmas Mangunreja

UPT Puskesmas Mangunreja. (2017). Profil Puskesmas Mangunreja

UPT Puskesmas Mangunreja. (2018). Profil Puskesmas Mangunreja 